\title{
THE INFLUENCE OF SEX HORMONES ON ANTIDEPRESSANT- INDUCED ALTERATIONS IN NEUROTRANSMITTER RECEPTOR BINDING $^{1}$
}

\author{
DAVID A. KENDALL, GEORGE M. STANCEL, AND S. J. ENNA² \\ Departments of Pharmacology and of Neurobiology and Anatomy, University of Texas Medical School at Houston, Houston, \\ Texas 77025
}

Received August 24, 1981; Revised November 2, 1981; Accepted November 6, 1981

\begin{abstract}
Long term (21-day) treatment with antidepressants induces a decrease in $\beta$-adrenergic and serotonin $_{2}\left(5-\mathrm{HT}_{2}\right)$ receptor binding in rat brain frontal cortex. Since hormone imbalances are known to be associated with affective illness, the present study was undertaken to determine whether sex hormones influence these alterations in neurotransmitter receptor binding. Using receptor binding assays, we found that castration abolishes the decline in the concentration of $5-\mathrm{HT}_{2}$, but not $\beta$ adrenergic, receptors brought on by chronic imipramine or iprindole treatment in both male and female rats. In contrast, the receptor responses to trazodone, mianserin, and pargyline were not influenced by surgery. Furthermore, mianserin was found to reduce $\beta$-adrenergic binding in intact females, but not males, suggesting a sex-related specificity with regard to the response to this agent. Testosterone and estrogen, but not dihydrotestosterone, reversed the effects of castration in males, suggesting that the interaction between the steroids and antidepressants is mediated through estrogenic, rather than androgenic, receptors. The results indicate that the receptor responses to some antidepressant drugs is dependent, at least in part, on the hormonal state of the animal.
\end{abstract}

Alterations in monoaminergic transmission appear to be related to the symptoms of depression (Schildkraut, 1965; Shopsin et al., 1974; Enna et al., 1981a). This theory is partially based on the fact that the predominant neurochemical effect of most antidepressants appears to be a modification of catecholamine and indolamine activity. For example, tricyclic antidepressants block transmitter uptake, whereas pargyline inhibits monoamine metabolism.

While alterations in presynaptic processes are undoubtedly crucial in mediating the antidepressant action of some agents, more recent data indicate that these drugs are also capable of influencing neurotransmission by modifying postsynaptic receptor integrity and function (Peroutka et al., 1977; Snyder and Yamamura, 1977; Richelson, 1978; Enna et al., 1981b). Thus, many antidepressants are rather potent as direct acting antagonists

\footnotetext{
'This work was supported in part by a grant from Mead Johnson and by United States Public Health Service Grants NS-13803 and HD 08615 and Research Career Development Awards NS-00335 (S. J. E.) and HD-00099 (G. M. S.). We thank Ms. Judy Ireland for technical assistance.

${ }^{2}$ To whom correspondence should be addressed at Departments of Pharmacology and of Neurobiology and Anatomy, University of Texas Medical School at Houston, P.O. Box 20708, Houston, TX 77025.
}

at histamine, $\alpha$-adrenergic, and cholinergic muscarinic receptors. Moreover, long term administration of antidepressants can modify receptor number and function for a variety of monoamine systems, with $\beta$-adrenergic and serotonin. $\left(5-\mathrm{HT}_{2}\right)$ receptors being particularly vulnerable in this regard (Banerjee et al., 1977; Maggi et al., 1980; Peroutka and Snyder, 1980a; Vetulani and Sulser, 1975; Enna et al., 1981b). Indeed, chronic administration of most antidepressants will, under the proper conditions, decrease the number or functional activity of brain $\beta$ adrenergic receptors as well as reduce the quantity of 5 $\mathrm{HT}_{2}$ binding sites. These findings are particularly intriguing since the average time necessary to observe these changes in receptor number is similar to the amount of time purported to be necessary for observing a subjective clinical response (Denber, 1975). Importantly, similar receptor alterations do not occur following long term treatment with other psychoactive drugs (Peroutka and Snyder, 1980a).

While there is little evidence to link changes in receptor number directly to modifications in behavior, the specificity of this neurochemical response with regard to antidepressants and the temporal correlation between the appearance of the receptor changes and clinical response suggest that the decreases in $\beta$-adrenergic and 5 - $\mathrm{HT}_{2}$ receptor binding and function may be an index of anti- 
depressant efficacy. Using this approach, it has been found that the imipramine-induced decline in $5-\mathrm{HT}_{2}$ receptor binding does not occur in ovariectomized rats, suggesting that sex hormones may play a vital role in the molecular, and possibly clinical, response to this drug (Kendall et al., 1981c).

In the present study, this interaction is examined in more detail to establish specificity with respect to the hormones involved, the antidepressants, and the sex of the animal. The results indicate that the response to all antidepressants is not affected similarly by gonadectomy and that males and females are affected equally. Furthermore, hormone replacement studies reveal that estrogen, rather than progesterone or testosterone, is the most likely mediator of this receptor response to some antidepressants.

\section{Materials and Methods}

Surgical procedures. Sprague-Dawley rats (150 to 175 $\mathrm{gm}$ ) of both sexes were used for all experiments, and surgical procedures were conducted using ether anesthesia. Bilateral ovariectomies were performed through a single midline incision on the dorsal surface of the animal. The success of surgery was verified at autopsy by measuring uterine weight. Male animals were castrated by surgical removal of both testes. All animals were housed normally (six to a cage) with a 12-hr light-dark cycle and were allowed free access to food and water.

Animals were killed by decapitation at various times after surgery and drug treatment. Brains were removed rapidly, dissected on ice, frozen on dry ice, and stored at $-20^{\circ} \mathrm{C}$ until assayed.

Hormone and drug treatment. For hormone treatments, animals were injected once daily, subcutaneously, with $17 \beta$-estradiol ( $10 \mu \mathrm{g} /$ animal/day), testosterone propionate ( $1 \mathrm{mg} / \mathrm{animal} / \mathrm{day})$, or dihydrotestosterone (DHT; $1 \mathrm{mg} /$ animal/day). All hormones were dissolved in a minimum volume of absolute ethanol, after which sesame oil was added and the mixture was heated at $60^{\circ} \mathrm{C}$ for $1 \mathrm{hr}$. Hormone treatments were initiated routinely $24 \mathrm{hr}$ after surgery and were continued throughout the study period. Sham-operated control animals received an equivalent volume of vehicle.

With antidepressants, treatment began no sooner than 7 days after surgery, and the animals received a single daily intraperitoneal injection of the drug throughout the treatment period. All antidepressants were dissolved in saline or distilled water just prior to injection and control animals received an equivalent volume of vehicle.

All hormone and antidepressant drug treatments were performed at the same time of day ( 3 to 4 P.M.), and the animals were killed $24 \mathrm{hr}$ following the last injection.

Receptor binding assays. $\beta$-Adrenergic and $5-\mathrm{HT}_{2}$ receptor binding in frontal cortex were conducted using previously published procedures (Bylund and Snyder, 1976; Peroutka and Snyder, 1979). Briefly, for $\beta$ receptor binding, the brain tissue was homogenized in $10 \mathrm{vol}$ of chilled $0.05 \mathrm{M}$ Tris- $\mathrm{HCl}$ buffer $\left(\mathrm{pH} 8.0\right.$ at $\left.25^{\circ} \mathrm{C}\right)$ and, following centrifugation at $48,000 \times g$ for $10 \mathrm{~min}$ at $4^{\circ} \mathrm{C}$, the supernatant was discarded and the pellet was resuspended in buffer as above. After a second centrifugation, the washed pellet was resuspended a final time to a concentration of 0.5 to $1.0 \mathrm{mg}$ of protein $/ \mathrm{ml}$. Portions of this homogenate were added, in triplicate, to culture tubes containing $0.2 \mathrm{nM}\left[{ }^{3} \mathrm{H}\right]$ dihydroalprenolol $\left(\left[{ }^{3} \mathrm{H}\right]\right.$ DHA; $4.5 \mathrm{Ci} / \mathrm{mmol}$ ). Nonspecific binding was determined by conducting the assay in the presence of $5 \mu \mathrm{m}$ propranolol. The final volume of the mixture was $1 \mathrm{ml}$, and the assay was conducted by incubating the membrane suspension at $25^{\circ} \mathrm{C}$ for $30 \mathrm{~min}$. The reaction was terminated by filtration over glass fiber filters $(\mathrm{GF} / \mathrm{C})$ maintained under reduced pressure. After rinsing with cold buffer, the filters were placed into scintillation vials containing $10 \mathrm{mil}$ of Aquasol (New England Nuclear) and then agitated for $3 \mathrm{hr}$ at room temperature, and radioactivity was quantified using liquid scintillation spectrometry.

For 5- $\mathrm{HT}_{2}$ receptor binding, the tissue was homogenized and resuspended as above using $0.05 \mathrm{M}$ Tris- $\mathrm{HCl}$ $\left(\mathrm{pH} 7.5\right.$ at $\left.25^{\circ} \mathrm{C}\right)$. Following the second centrifugation, the pellet was resuspended in buffer and the homogenate was incubated at $37^{\circ} \mathrm{C}$ for $10 \mathrm{~min}$. After a final centrifugation, the tissue was resuspended in buffer containing 1 $\mathrm{gm} / \mathrm{liter}$ of ascorbic acid, $1.96 \mathrm{mg} / \mathrm{liter}$ of pargyline, and $0.59 \mathrm{gm} /$ liter of $\mathrm{CaCl}_{2}$. The homogenate was incubated at $37^{\circ} \mathrm{C}$ for $15 \mathrm{~min}$ and then cooled on ice for $15 \mathrm{~min}$. For assay, portions ( 0.5 to $1 \mathrm{mg}$ of protein) of this homogenate were placed, in triplicate, into culture tubes containing $0.3 \mathrm{nM}\left[{ }^{3} \mathrm{H}\right]$ spiroperidol $(29 \mathrm{Ci} / \mathrm{mmol})$ in the presence and absence of $100 \mu \mathrm{M}$ serotonin (blank). The final incubation volume was $1 \mathrm{ml}$ and the samples were incubated at $37^{\circ} \mathrm{C}$ for $15 \mathrm{~min}$, with the reaction terminated and radioactivity quantified as above.

For receptor binding site saturation studies, membranes were incubated in the presence of various concentrations of $\left[{ }^{3} \mathrm{H}\right]$ spiroperidol $(0.1$ to $4 \mathrm{nM})$ in the presence and absence of unlabeled serotonin. For both $\beta$-adrenergic and $5-\mathrm{HT}_{2}$ binding assays, specific receptor binding was defined as the amount of radioactivity displaced by the unlabeled ligand. Protein was assayed by the method of Lowry et al. (1951).

Statistics. The significance of the difference between means was evaluated by a one-way analysis of variance and a Student Newman-Keuls multiple range test $(n \geq$ 6 ). Differences were considered statistically significant when $p \leq 0.05$.

Drugs and chemicals. All radioisotopes were purchased from New England Nuclear (Boston, MA). The following antidepressants were kindly donated by their manufacturers: trazodone, Mead Johnson, Evansville, IN; imipramine, Geigy Pharmaceuticals, Summitt, NJ; mianserin, Organon, Oss, Holland; and iprindole, Wyeth Laboratories, Philadelphia, PA. Pargyline, $\beta$-estradiol, testosterone propionate, and dihydrotestosterone all were purchased from Sigma Chemical Co. (St. Louis, $\mathrm{MO}$ ). All other chemicals and reagents were purchased from commercial suppliers.

\section{Results}

The influence of castration on imipramine-induced receptor modifications in female rat brain. In an earlier report (Kendall et al., 1981c), data were presented to indicate that ovariectomy prevents the imipramine-induced reduction in $5-\mathrm{HT}_{2}$, but not $\beta$-adrenergic, receptor binding in rat brain frontal cortex. In order to determine whether castration altered the time course of the changes in receptor binding, groups of ovariectomized and sham- 
operated controls were treated with $10 \mathrm{mg} / \mathrm{kg}$ of imipramine once daily for various lengths of time and cortical $\beta$-adrenergic and $5-\mathrm{HT}_{2}$ receptor binding were evaluated during the course of treatment (Fig. 1). In sham-operated controls, $\beta$-adrenergic receptor binding was significantly and maximally reduced $(20 \%)$ during the first 10 days of treatment as compared to untreated animals. On the other hand, between 10 and 21 days of treatment were necessary before a significant reduction $(47 \%)$ in $5-\mathrm{HT}_{2}$ receptor binding was noted in these animals. Ovariectomy had no effect on either the time course or the extent of the reduction in $\beta$-adrenergic binding, but ovariectomy prevented the reduction in $5-\mathrm{HT}_{2}$ binding which was observed in sham-operated controls (Fig. 1).

Receptor binding saturation analysis revealed that the imipramine-induced decrease in $5-\mathrm{HT}_{2}$ receptor binding in intact animals was due entirely to a reduction in the concentration of binding sites $\left(B_{\max }\right)$, with no change in receptor affinity $\left(K_{d}\right)$ (Fig. 2). Thus, the $B_{\max }$ for $5-\mathrm{HT}_{2}$ receptor binding in frontal cortex of intact imipraminetreated animals was $40 \%$ lower than that found in untreated controls. Saturation analysis also indicated that
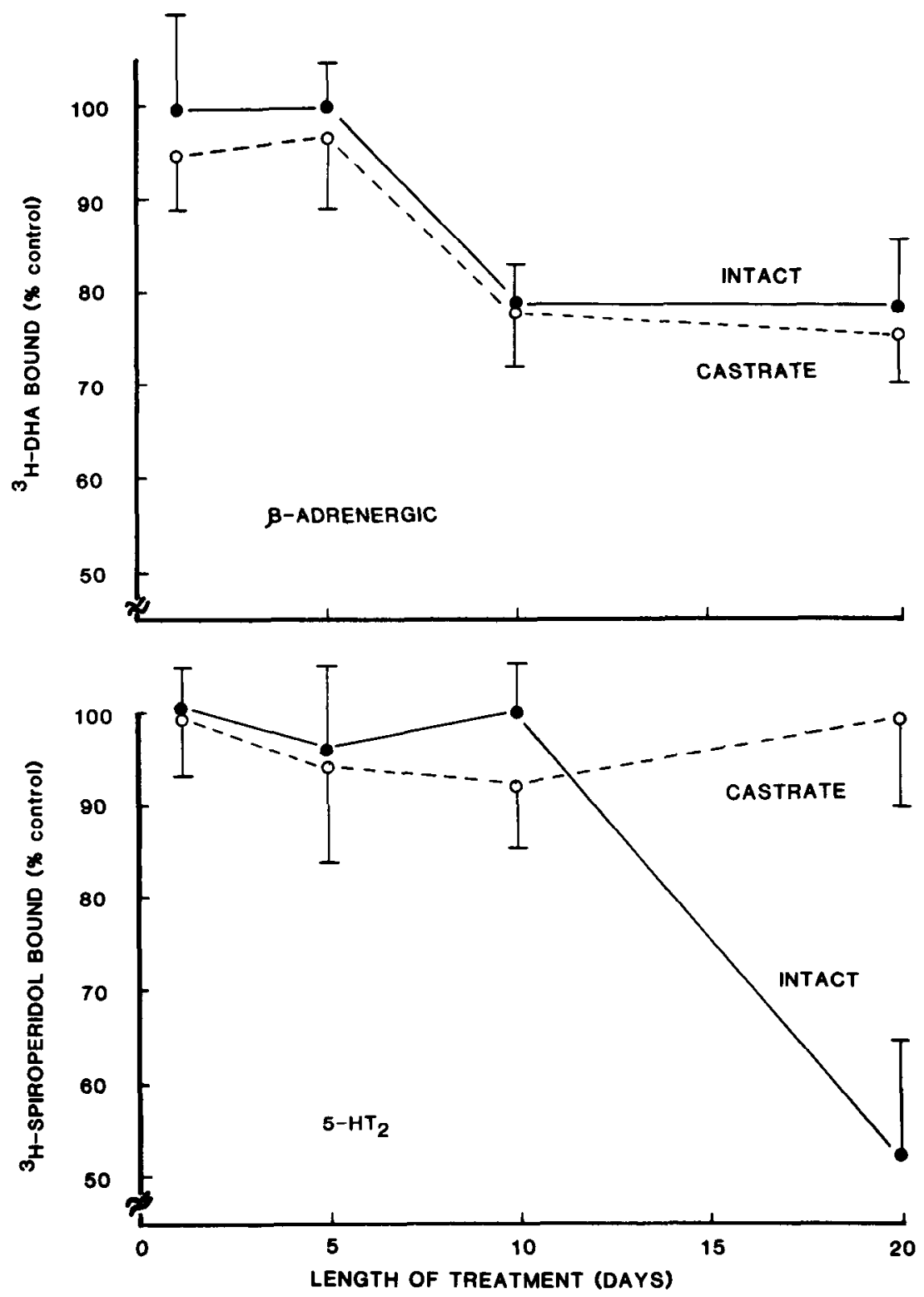

Figure 1. Time course of imipramine-induced changes in $\beta$-adrenergic and $5-\mathrm{HT}_{2}$ receptor binding in the frontal cortex of intact and castrate female rats. Imipramine $(10 \mathrm{mg} / \mathrm{kg}$, once daily, i.p.) treatment was initiated in the different groups at various times after surgery such that sacrifice occurred 28 days following castration in all cases. All animals were decapitated on the same day, $24 \mathrm{hr}$ after the last drug treatment. $\beta$-Adrenergic and $5-\mathrm{HT}_{2}$ receptor binding were analyzed in frontal corlex using $\left[{ }^{3} \mathrm{H}\right] \mathrm{DHA}$ and $\left[{ }^{3} \mathrm{H}\right]$ spiroperidol as ligands. Each point represents the mean of six animals, each of which was analyzed in triplicate. Control (intact, no drug treatment) values were $54 \pm 4 \mathrm{fmol} / \mathrm{mg}$ of protein for $\left[{ }^{3} \mathrm{H}\right] \mathrm{DHA}$ binding and $29 \pm 2 \mathrm{fmol} / \mathrm{mg}$ of protein for $\left[{ }^{3} \mathrm{H}\right]$ spiroperidol binding. $p<0.05$ compared to intact, untreated controls. 


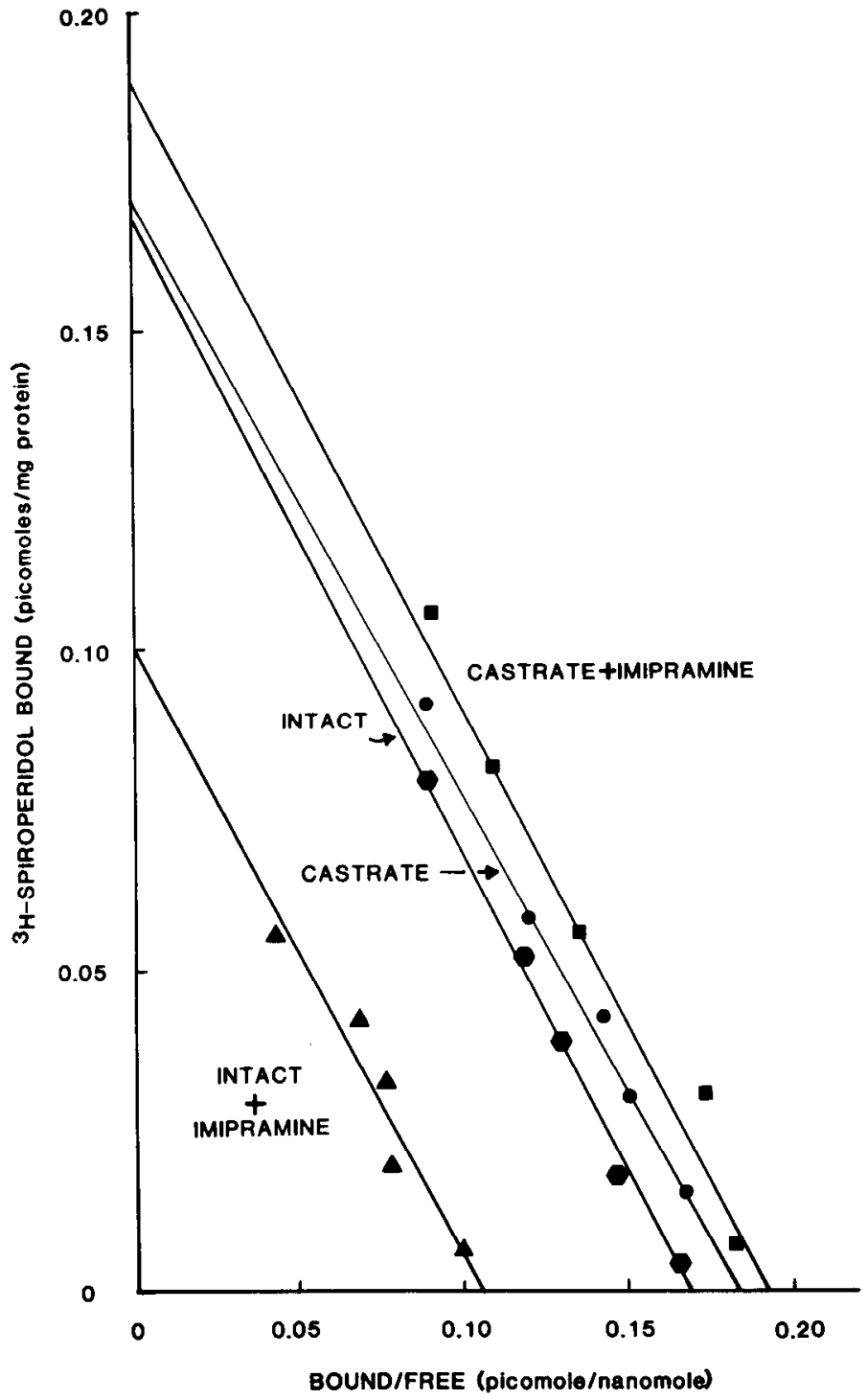

Figure 2. Effect of castration and chronic imipramine treatment on $5-\mathrm{HT}_{2}$ receptor binding site concentration $\left(B_{\max }\right)$ and affinity $\left(K_{d}\right)$ in the frontal cortex of female rat brain. Specific binding was determined by incubating the brain membranes with increasing concentrations of $\left[{ }^{3} \mathrm{H}\right]$ spiroperidol $(0.1$ to 4.0 $\mathrm{nM}$ ) in the presence and absence of $100 \mu \mathrm{M}$ serotonin. Each point is the mean of data derived from three animals, each of which was analyzed in triplicate. Intercepts were calculated by linear regression analysis. Estimated $K_{d}$ (nanomolar concentrations) and $B_{\max }$ (femtomoles/mg of protein) values were as follows: intact controls, $0.99 \pm 0.10$ and $168 \pm 12$; castrate controls, $0.93 \pm 0.11$ and $171 \pm 18$; intact + imipramine, $0.94 \pm$ 0.09 and $100 \pm 15$ ( $p<0.05$ compared to intact controls); castrate + imipramine, $0.98 \pm 0.12$ and $190 \pm 23$.

castration itself had no significant influence on either the $B_{\max }$ or $K_{d}$ for this binding site. Furthermore, in the castrate group, there were no significant differences in $B_{\max }$ or $K_{d}$ after 21 days of imipramine treatment relative to untreated controls and untreated castrates. Others have shown that antidepressant-induced decreases in $\beta$ adrenergic receptor binding are due primarily to a reduction in $B_{\max }$ (Banerjee et al., 1977).

The influence of castration on 5-HT $\mathrm{T}_{2}$ and $\beta$-adrenergic receptor reductions induced by a variety of antidepressants in male and female rats. In order to determine whether the apparent interaction between sex steroids and $5-\mathrm{H}^{\prime} \mathrm{T}_{2}$ receptors is peculiar for imipramine, the influence of castration on the $5-\mathrm{HT}_{2}$ receptor response to a variety of other antidepressants was examined in both male and female rats (Table I). With respect to females, only imipramine and iprindole treatment were modified significantly by castration, with trazodone, mianserin, and pargyline all inducing similar, and significant, reductions in $5-\mathrm{HT}_{2}$ binding in both intact and castrate animals. In intact females, $5-\mathrm{HT}_{2}$ receptor binding was decreased almost $50 \%$ following 21 days of continuous treatment with iprindole, whereas with castrates, the drug reduced binding only $15 \%$.

While fewer drugs were tested, a similar pattern of response was observed with male rats (Table I). Thus, with castrate males, there was no significant reduction in cortical $5-\mathrm{HT}_{2}$ receptor binding following 21 days of treatment with imipramine $(10 \mathrm{mg} / \mathrm{kg})$ or iprindole $(10$ $\mathrm{mg} / \mathrm{kg}$ ), whereas both drugs induced a 30 to $50 \%$ reduction in binding in intact animals. However, as with females, castration had no influence on the reduction in 5$\mathrm{HT}_{2}$ receptor binding observed following chronic treatment with mianserin.

With regard to the $\beta$-adrenergic receptor system, only imipramine, mianserin, and pargyline caused significant reductions in binding in intact females at the doses and during the time period (21 days) examined (Table II). As reported previously (Kendall et al., 1981c), castration had no effect on the imipramine-induced decline in $\beta$-adrenergic binding in females, and the present results indicate that pargyline is similarly unaffected. However, castration significantly attenuated the $\beta$-adrenergic receptor response to mianserin in the female rats, with no significant reduction observed in the operated animals although there was over a $20 \%$ decline in binding in the shamoperated controls (Table II).

With males, imipramine was the only drug tested that induced a significant decline in $\beta$-adrenergic receptor binding using this treatment protocol and, as with fe-

\section{TABLE I}

Effect of castration on antidepressant-induced changes in 5-HT

receptor binding in the frontal cortex of male and female rats

Male or female Sprague-Dawley rats received once daily intraperitoneal injections of an antidepressant or an equivalent volume of saline at the doses listed. Drug treatment commenced 7 days after surgery and continued for 21 consecutive days. The animals were decapitated $24 \mathrm{hr}$ after the last injection and the brains were removed rapidly, dissected, and stored at $-20^{\circ} \mathrm{C}$ until assayed for $5-\mathrm{HT}_{2}$ receptor binding using $\left[{ }^{3} \mathrm{H}\right]$ spiroperidol as a ligand. In all cases, the tissue was stored for less than 3 days prior to assay. Each value represents the mean \pm SEM of six to eight animals, each of which was analyzed in triplicate.

\begin{tabular}{|c|c|c|c|c|c|}
\hline \multirow{3}{*}{ Treatment } & \multirow{3}{*}{ Dose } & \multicolumn{4}{|c|}{ 5-HT.2 Receptor Rinding } \\
\hline & & \multicolumn{2}{|c|}{ Males } & \multicolumn{2}{|c|}{ Females } \\
\hline & & Intact & Castrate & Intact & Castrate \\
\hline & $m g / k g$ & \multicolumn{4}{|c|}{ fmol/mg protein } \\
\hline Saline & & $31 \pm 2$ & $29 \pm 2$ & $31 \pm 2$ & $33 \pm 1$ \\
\hline Imipramine & 10 & $20 \pm 3^{a}$ & $28 \pm 2$ & $19 \pm 2^{a}$ & $29 \pm 2$ \\
\hline Trazodone & 20 & & & $17 \pm 3^{\alpha}$ & $16 \pm 1^{a}$ \\
\hline Mianserin & 10 & $19 \pm 2^{a}$ & $16 \pm 1^{a}$ & $15 \pm 1^{\alpha}$ & $16 \pm 1^{a}$ \\
\hline Pargyline & 20 & & & $15 \pm 1^{\prime \prime}$ & $16 \pm 2^{a}$ \\
\hline Iprindole & 10 & $16 \pm 2^{a}$ & $24 \pm 3$ & $17 \pm 3^{a}$ & $26 \pm 2^{\alpha}$ \\
\hline
\end{tabular}

${ }^{a} p<0.05$ compared to saline-treated controls. 
TABLE II

Effect of castration on antidepressant-induced changes in $\beta$-adrenergic receptor binding in the frontal cortex of male and female rats

Male or female Sprague-Dawley rats received once daily intraperitoneal injections of an antidepressant or an equivalent volume of saline at the dosage listed. Drug treatment commenced 7 days after surgery and continued for 21 consecutive days. The animals were decapitated $24 \mathrm{hr}$ after the last injection and the brains were removed rapidly, dissected, and stored at $-20^{\circ} \mathrm{C}$ until assayed for $\beta$-adrenergic receptor binding using $\left[{ }^{3} \mathrm{H}\right] \mathrm{DHA}$ as a ligand. In all cases, the tissue was stored less than 3 days prior to assay. Each value represents the mean $\pm S E M$ of six to eight animals, each of which was analyzed in triplicate.

\begin{tabular}{|c|c|c|c|c|c|}
\hline \multirow{3}{*}{ Treatment } & \multirow{3}{*}{ Dose } & \multicolumn{4}{|c|}{$\beta$-Adrenergic Receptor Binding } \\
\hline & & \multicolumn{2}{|c|}{ Males } & \multicolumn{2}{|c|}{ Females } \\
\hline & & Intact & Castrate & Intact & Castrate \\
\hline & $m g / k g$ & \multicolumn{4}{|c|}{ fmol/mg protein } \\
\hline Saline & & $49 \pm 2$ & $52 \pm 2$ & $51 \pm 2$ & $53 \pm 2$ \\
\hline Imipramine & 10 & $40 \pm 2^{a}$ & $38 \pm 2^{u}$ & $38 \pm 2^{a}$ & $41 \pm 2^{a t}$ \\
\hline Trazodone & 20 & & & $48 \pm 3$ & $46 \pm 2$ \\
\hline Mianserin & 10 & $49 \pm 2$ & $48 \pm 3$ & $39 \pm 2^{a}$ & $47 \pm 3$ \\
\hline Pargyline & 20 & & & $30 \pm 3^{a}$ & $36 \pm 4^{u t}$ \\
\hline Iprindole & 10 & $49 \pm 3$ & $47 \pm 2$ & $50 \pm 5$ & $55 \pm 3$ \\
\hline
\end{tabular}

" $p<0.05$ compared to saline-treated controls.

males, castration had no influence on this response. In contrast to females, however, mianserin had no significant effect on $\beta$ receptor binding in intact males. For both neurotransmitter receptor binding systems, no significant differences were noted in base line binding between male and female rats, either in the intact or castrate groups (Tables I and II).

Reversibility of the castration effect. Earlier work has shown that the effect of castration on the imipramineinduced decline in $5-\mathrm{HT}_{2}$ receptor binding in female rats is reversed by the administration of estrogen or progesterone (Kendall et al., 1981c). In the present study, the reversibility in male rats was explored (Table III). Once again, chronic (21-day) treatment with imipramine was observed to have no effect on $5-\mathrm{HT}_{2}$ receptor binding in castrate males. However, co-administration of testosterone $(1 \mathrm{mg} /$ animal/day) or estradiol $(10 \mu \mathrm{g} / \mathrm{animal} /$ day $)$ once daily to castrate males treated with the antidepressant resulted in a significant reduction in binding. On the other hand, DHT (1 mg/animal/day) treatment was unable to overcome the castration effect (Table III). Other experiments revealed that, when given alone to either castrate or intact males or in combination with imipramine in intact animals, none of these hormones had any significant influence on either base line $\beta$-adrenergic or $5-\mathrm{HT}_{2}$ receptor binding or imipramine-induced changes in these systems (data not shown).

The effect of sex steroids on $\beta$-adrenergic and $5-\mathrm{HT}_{2}$ receptor binding in vitro. To examine whether sex hormones can influence ligand binding to $\beta$-adrenergic and $5-\mathrm{HT}_{2}$ receptor sites directly, receptor binding was analyzed in the presence and absence of $1 \mu \mathrm{M} \beta$-estradiol, progesterone, or testosterone using brain membranes obtained from intact untreated female rats. In these experiments, the influence of hormones on the potency of receptor site agonists and antagonists to displace radioligand was explored. In no case did any of the hor-

\section{TABLE III}

Effect of hormones on imipramine-induced changes in 5.HT: receptor binding in frontal cortex of castrate males

All animals used in these experiments were castrates. Once daily hormone treatment commenced 2 days after castration and continued throughout the course of the experiment. In all cases, imipramine treatment was initiated 7 days after surgery and was administered once a day at $10 \mathrm{mg} / \mathrm{kg}$ (i.p.) for 21 days. Dihydrotestosterone ( $1 \mathrm{mg} / \mathrm{animal} /$ day), testosterone ( $\mathrm{Img} / \mathrm{animal} /$ day), and $17 \beta$-estradiol $(10 \mu \mathrm{g} / \mathrm{animal} /$ day) were administered subcutaneously. All animals were decapitated $24 \mathrm{hr}$ after the last injection, and the brains were removed rapidly, dissected, and stored at $-20^{\circ} \mathrm{C}$ until assayed for $5-\mathrm{HT}_{2}$ receptor binding using $\left[{ }^{3} \mathrm{H}\right]$ spiroperidol as a ligand. Each value represents the mean \pm SEM of six to eight animals, each of which was analyzed in triplicate.

\begin{tabular}{lcc}
\hline \multicolumn{1}{c}{ Treatment } & $\begin{array}{c}\text { Treatment } \\
\text { Period }\end{array}$ & $\begin{array}{c}\text { 5-HT Receptor } \\
\text { Binding }\end{array}$ \\
\hline Saline & days & fmol/mg protein \\
Imipramine & 21 & $32 \pm 3$ \\
$\quad$ + Dihydrotestosterone & 21 & $30 \pm 2$ \\
+ Testosterone & 26 & $30 \pm 2$ \\
+ Estradiol & 26 & $25 \pm 2^{\prime \prime}$ \\
\hline
\end{tabular}

" $p<0.05$ compared to saline-treated castrates.

mones significantly influence either base line radioligand binding or the potency of agonists (serotonin for $5-\mathrm{H}^{\prime} \mathrm{T}_{2}$ receptors and isoproterenol for $\beta$-adrenergic receptors) or antagonists (spiroperidol for $5-\mathrm{HT}_{2}$ receptors and propranolol for $\beta$-adrenergic receptors) to inhibit radioligand binding (data not shown).

\section{Discussion}

A number of reports have indicated that hormones are capable of influencing brain neurotransmitter receptor binding and function as well as drug-induced alterations in these sites (Kendall et al., 1981a, b, c; Enna et al., 1981 a, b; Wagner and Davies, 1980; Rainbow et al., 1980; Savageau and Beatty, 1981; Hruska and Silbergeld, 1980; Chiodo et al., 1981). Since antidepressants may act, in part, by modifying the number and function of certain brain neurotransmitter receptors (Enna et al., 1981b) and since hormone imbalances are known to be associated with a variety of depressive disorders (Prange et al., 1977; Halbreich et al., 1979; deWied, 1980; Schlesser et al., 1980), studies have been undertaken to determine whether the neurochemical response to these drugs might be dependent upon the hormonal state of the animal. Previous results have indicated that the imipramine-induced decline in $5-\mathrm{HT}_{2}$ receptor binding in female rat brain is dependent upon the presence of sex steroids (Kendall et al., 1981b, c). The present results confirm and extend this initial observation.

The time course study revealed that castration completely prevents the imipramine-induced decline in 5$\mathrm{HT}_{2}$ binding during the 21-day treatment without affecting the response in $\beta$-adrenergic receptors. Receptor binding saturation analysis indicates that castration prevents the antidepressant-induced reduction in the concentration of $5-\mathrm{HT}_{2}$ receptor sites without influencing the affinity of the receptor for the radioligand. Furthermore, these experiments revealed that the decrease in $\beta$-adrenergic receptor binding precedes the $5-\mathrm{HT}_{2}$ receptor decline with the former occurring within the first 10 
days of treatment, whereas the latter required 10 to 20 days of drug administration. While it might be argued that the time course of the reduction in $5-\mathrm{HT}_{2}$ receptor binding better coincides with the reported therapeutic effect than the change in $\beta$ receptors, the variability in the time to clinical response is too great to support such speculation.

The interaction between gonadal hormones and antidepressants also appears to be somewhat drug specific. Thus, of the antidepressants tested, only imipramine and iprindole were influenced significantly by castration, whereas the $5-\mathrm{HT}_{2}$ receptor response to trazodone, mianserin, and pargyline was unaffected. With regard to the $5-\mathrm{HT}_{2}$ receptor, both male and female rats appeared to respond in a similar manner. In contrast, $\beta$-adrenergic receptor modifications appeared to be more resistant to hormonal manipulation. However, although mianserin was incapable of decreasing $\beta$-adrenergic receptor binding in intact male rats under the present conditions, it did cause a significant decline in intact females, suggesting that females may be more sensitive to the action of this drug. Furthermore, castration modified the mianserin-induced $\beta$-adrenergic receptor decline in females, indicating that, with some drugs at least, sex hormones may influence $\beta$-adrenergic responses.

While it is conceivable that the reduction in receptor binding noted following long term treatment with antidepressants may be due to the presence of residual drug in brain membranes, others have shown that this is probably not an important factor under the conditions used in the present experiments (Peroutka and Snyder, 1980b). Moreover, it could be argued that the apparent decrease in the effectiveness of some drugs to alter receptor binding in castrate animals may be the result of a change in drug metabolism rather than to some receptor interaction at a molecular level. This too would seem unlikely since, in all cases, either $\beta$-adrenergic or $5-\mathrm{HT}_{2}$ receptor binding is affected, not both as might be expected if the drug was more rapidly metabolized or excreted. Furthermore, it also has been reported that, for imipramine at least, the drug-induced decline in $5-\mathrm{HT}_{2}$ receptor binding is observed in cerebral cortex but not hippocampus, which also would argue against a significant alteration in the circulating levels of the drug (Kendall et al., 1981c). Finally, castration has been shown to have a negligible effect on the hepatic metabolism of imipramine at least in female rats (Skett et al., 1980). Accordingly, the differential effect of castration on the receptor responses to various antidepressant drugs suggests that, while virtually all antidepressants are capable of reducing the number of $5-\mathrm{HT}_{2}$ receptors, the molecular mechanisms involved may differ.

Further evidence that sex hormones are crucial for this receptor change was provided by the hormone replacement experiments. Thus, with males, treatment with testosterone or estradiol overcame the effects of castration. Importantly, DHT was found to be inactive in this regard. This suggests that estrogenic rather than androgenic receptors are the most likely mediators of this response since, while a significant amount of testosterone is aromatized to estrogen, little DHT is metabolized to this steroid (McEwen, 1981).
The precise mechanism whereby sex hormones influence drug-induced changes in neurotransmitter receptor number is unknown. While it is possible that these steroids may modify binding and function by directly interacting with the receptor recognition site, the fact that they failed to modify receptor binding when added in vitro would seem to argue against such an action. Alternatively, it is conceivable that the sex hormones may influence receptor turnover by affecting protein synthesis, although this too seems unlikely in light of the fact that not all antidepressants are affected similarly. It is possible, however, that steroids could have a selective effect on the synthesis of specific proteins.

A third possibility is that the hormones may modify some aspect of neurotransmitter turnover, release, or reuptake and, in this way, indirectly influence the change in receptor number since the receptor response to many antidepressants is undoubtedly dependent upon presynaptic activity. Indeed, it is well established that gonadal hormones can influence a variety of presynaptic processes (Luine et al., 1980; Beattie et al., 1972; Holzbaurer and Youdim, 1973; Hackman et al., 1973).

A final possibility is that the neurotransmitter receptor binding changes observed in this study are secondary to an alteration in hypothalamic-pituitary hormone release induced by castration. For example, prolactin levels are regulated to some extent by estradiol, and prolactin is known to modify neurotransmitter turnover in brain (McEwen, 1981). Furthermore, adrenocorticotropic hormone secretion is reduced in ovariectomized animals (Coyne and Kitay, 1969).

Regardless of the precise mechanism, the present data indicate that antidepressant-induced modifications in neurotransmitter receptor binding sites are dependent upon circulating levels of sex hormones and that the molecular mechanism by which antidepressants decrease recognition site binding may differ within this drug class. If these alterations in receptor binding are related to therapeutic efficacy, these findings may provide a clue as to why a significant number of patients fail to respond to antidepressant therapy. More precise information about the interactions among hormones, antidepressants, and neurotransmitter receptors may provide a better understanding of the mechanism of action of this drug class at a molecular level and more clearly define the neurochemical and hormonal influences in the etiology of depression.

\section{References}

Banerjee, S. P., L. S. Kung, S. Riggi, and S. K. Chanda (1977) Development of $\beta$-adrenergic receptor subsensitivity by antidepressants. Nature 268: 455-456.

Beattie, C. W., C. H. Rodgers, and L. F. Soyka (1972) Influence of ovariectomy and ovarian steroids on hypothalamic tyrosine hydroxylase activity in the rat. Endocrinology 91: 276-279.

Bylund, D. B., and S. H. Snyder (1976) $\beta$-Adrenergic binding in membrane preparations from mammalian brain. Mol. Pharmacol. 12: 568-580.

Chiodo, L. A., A. R. Caggiula, and C. F. Saller (1981) Estrogen potentiates the stereotypy induced by dopamine agonists in the rat. Life Sci. 28: 827-835.

Coyne, M. D., and J. I. Kitay (1969) Effect of ovariectomy on pituitary secretion of ACTH. Endocrinology 85: 1097-1102. 
Denber, H. C. B. (1975) Pharmacotherapy of depression. In Psychopharmacological Treatment-Theory and Practice, H. C. B. Denber, ed., pp. 121-135, Marcel Dekker, New York. deWied, D. (1980) Neuropeptides and psychopathology. Endeavour 4: 154-159.

Enna, S. J., J. B. Malick, and E. Richelson, eds. (1981a) Antidepressants: Neurochemical, Behavioral and Clinical Perspectives, Raven Press, New York.

Enna, S. J., E. Mann, D. A. Kendall, and G. M. Stancel (1981b) Effect of chronic antidepressant administration on brain neurotransmitter receptor binding. In Antidepressants: Neurochemical, Behavioral and Clinical Perspectives, S. J. Enna, J. B. Malick, and E. Richelson, eds., pp. 91-105, Raven Press, New York.

Hackman, E., A. Wirz-Justice, and M. Lichesteinev (1973) The uptake of dopamine and serotonin in rat brain during progesterone decline. Psychopharmacologia 32: 189-191.

Halbreich, U., L. Grunhaus, and M. Ben-David (1979) Twentyfour hour rhythm of prolactin in depressive patients. Arch. Gen. Psychiatry 36: 1183-1186.

Holzbaurer, M., and M. B. H. Youdim (1973) The oestrus cycle and monoamine oxidase activity. Br. J. Pharmacol. 48: 600608 .

Hruska, R. E., and E. K. Silbergeld (1980) Increased dopamine receptor sensitivity after estrogen treatment using the rat rotation model. Science 208: 1466-1468.

Kendall, D. A., B. S. McEwen, and S. J. Enna (1981a) The influence of ACTH and corticosterone on ${ }^{3} \mathrm{H}-\mathrm{GABA}$ receptor binding in rat brain. Brain Res., in press.

Kendall, D. A., J. Slopis, R. Duman, G. M. Stancel, and S. J. Enna (1981b) The influence of hormones on drug-induced modifications in neurotransmitter receptor binding. In Proteins of the Nervous System-Structure and Function, B. Haber, J. K. Perez-Polo, and J. D. Coulter, eds., pp. 193-207, Alan R. Liss, New York.

Kendall, D. A., G. M. Stancel, and S. J. Enna (1981c) Imipramine: Effect of ovarian steroids on modifications in serotonin receptor binding. Science 211: 1183-1185.

Lowry, O. H., N. J. Rosebrough, A. L. Farr, and R. J. Randall (1951) Protein measurement with the Folin phenol reagent. J. Biol. Chem. 193: 265-275.

Luine, V., D. Park, T. Joh, D. Reis, and B. McEwen (1980) Immunochemical demonstration of increased choline acetyltransferase concentration in rat preoptic area after estradiol administration. Brain Res. 191: 273-277.

Maggi, A., D. C. U'Prichard, and S. J. Enna (1980) Differential effects of antidepressant treatment on brain monoaminergic receptors. Eur. J. Pharmacol. 61: 91-98.

McEwen, B. S. (1981) Neural gonadal steroid actions. Science 211: 1303-1311.

Peroutka, S. J., and S. H. Snyder (1979) Multiple serotonin receptors: Differential binding of ${ }^{3} \mathrm{H}-5$-hydroxytryptamine,
${ }^{3} \mathrm{H}$-lysergic acid diethylamide and ${ }^{3} \mathrm{H}$-spiroperidol. Mol. Pharmacol. 16: 687-699.

Peroutka, S. J., and S. H. Snyder (1980a) Long-term antidepressant treatment lowers spiroperidol labeled serotonin receptor binding. Science 21: 88-90.

Peroutka, S. J., and S. H. Snyder (1980b) Regulation of serotonin $_{2}\left(5-\mathrm{HT}_{2}\right)$ receptors labeled with ${ }^{3} \mathrm{H}$-spiroperidol by chronic treatment with the antidepressant amitriptyline. J. Pharmacol. Exp. Ther. 215: 582-587.

Peroutka, S. J., D. C. U'Prichard, D. A. Greenberg, and S. H Snyder (1977) Neuroleptic drug interactions with norepinephrine alpha receptor binding sites in rat brain. Neuropharmacology 16: 549-556.

Prange, A. J., M. A. Lipton, C. B. Nemeroff, and I. C. Wilson (1977) The role of hormones in depression. Life Sci. 20:13051318.

Rainbow, T. C., V. Degroff, V. N. Luine, and B. S. McEwen (1980) Estradiol-17- $\beta$ increases the number of muscarinic receptors in hypothalamic nuclei. Brain Res. 198: 239-243.

Richelson, E. (1978) Tricyclic antidepressants block histamine $\mathrm{H}_{1}$ receptors of mouse neuroblastoma cells. Nature 274: 176177.

Savageau, M. W., and W. W. Beatty (1981) Gonadectomy and sex differences in the behavioral responses to amphetamine and apomorphine of rats. Pharmacol. Biochem. Behav. 14: 17-21.

Schildkraut, J. J. (1965) The catecholamine hypothesis of affective disorders. A review of supporting evidence. Am. J. Psychiatry 122: 509-522.

Schlesser, M. A., G. Winokur, and B. M. Sherman (1980) Hypothalamic-pituitary-adrenal axis activity in depressive illness. Arch. Gen. Psychiatry 37: 737-743.

Shopsin, B., S. Wilk, G. Sathananthan, S. Gershon, and K. Davis (1974) Catecholamines and affective disorders revised: A critical assessment. J. Nerv. Ment. Dis. 158: 369-383.

Skett, P., A. Mode, J. Rafter, L. Sahlin, and J. A. Gustafsson (1980) The effects of gonadectomy and hypophysectomy on the metabolism of imipramine and lidocaine by the liver of male and female rats. Biochem. Pharmacol. 29: 2759-2762.

Snyder, S. H., and H. I. Yamamura (1977) Antidepressants and the muscarinic acetylcholine receptor. Arch. Gen. Psychiatry 34: 236-239.

Vetulani, J., and F. Sulser (1975) Actions of various antidepressant treatments reduce reactivity of noradrenergic cyclic AMP generating system in limbic forebrain. Nature 257: 495496.

Wagner, H. R., and J. N. Davies (1980) Decreased $\beta$-adrenergic responses in the female rat brain are eliminated by ovariectomy: Correlation of ${ }^{3} \mathrm{H}$-dihydroalprenolol binding and catecholamine stimulated cyclic AMP levels. Brain Res. 201: 235 239. 